J. Clin. Chem. Clin. Biochem.

Vol. 18. 1980, pp. 921-927

\title{
Evaluation of the Assay for Serum Monoamine Oxidase - an Index of Hepatic Fibrosis
}

\author{
By A. M. Gressner
}

Department of Clinical Chemistry and Pathobiochemistry of the Medical Faculty of the RWTH, Aachen, FRG

(Received March 18/June 13, 1980)

Summary: At present, neither the diagnostic efficiency, the analytic reliability, nor the practicability of clinical chemical tests for estimation of the degree and/or activity of the fibrotic transformation of the chronically injured liver are satisfactory. Among the various parameters proposed, the determination of the activity of monoamine oxidase (monoamine: $\mathrm{O}_{2}$ oxidoreductase, EC 1.4.3.4) in serum seems to be advantageous. To facilitate its routine use we studied some important practical aspects of the new colorimetric assay for the activity of monoamine oxidase in serum.

The reaction procedes linearly with time for at least two hours and with enzyme concentrations up to $6 \mathrm{kU} / \mathrm{l}$.

The buffer composition influences markedly the function of the enzyme; in Tris- $\mathrm{HCl}$ buffer ( $\mathrm{pH} 7.2)$ at $37^{\circ} \mathrm{C}$ the activity is 1.35 times higher than in phosphate buffer $(\mathrm{pH} 7.3)$ and the temperature correction factors are also different for both buffer systems.

$0.003 \mathrm{~mol} / \mathrm{l}$ of the lathyrogenic compound $\beta$-aminopropionitrile inhibits the activity by about $50 \%$ whereas $\mathrm{Cu}^{2+}$ up to $130 \mu \mathrm{mol} / 1$ does not affect enzyme function.

Intra- and interassay precision are characterized by a CV of 3.6 and $12 \%$, respectively.

Hemolysis and hyperbilinbinemia do not interfere significantly with the determination but in hyperlipemic sera elevated enzyme activities were noticed.

During storage of serum at room temperature the catalytic function decreases by about $30 \% /$ day.

Of the 26 quality control sera tested, only a few contained monoamine oxidase activity that was quantitatively (i.e. similar-catalytic activity concentration) and qualitatively (i.e. comparable sensitivity to $\beta$-aminopropionitrile and ratio of activity in tris phosphate buffer) similar to that in human serum, and were therefore suitable for routine precision control analysis.

\section{Bewertung der Aktivitätsbestimmung der Monoaminoxidase im Serum - ein Parameter der Leberfibrose}

Zusammenfassung: Gegenwärtig sind weder die diagnostische und analytische Zuverlässigkeit noch die Praktikabilität klinisch-chemischer Testverfahren zur Erfassung des Grades und/oder der Aktivität der fibrotischen Transformation der chronisch geschädigten Leber zufriedenstellend. Unter den verschiedenen vorgeschlagenen Kenngrößen erweist sich die Aktivitätsbestimmung der Monoaminoxidase (Monoamino: $\mathrm{O}_{2}$ Oxidoreduktase, EC 1.4.3.4) im Serum als vorteilhaft. Um ihre routinemäßige Anwendung zu erleichtern, untersuchten wir einige praktisch wichtige Aspekte des neuen kolorịmetrischen Bestimmungsverfahren der Aktivität der Monoamino Oxidase im Serum.

Die Reaktion verläuft bis żu einer katalytischen Konżentration des Enzyms von $6 \mathrm{kU} / \mathrm{l}$ und für einen Zeitraum von mindestens 2 Stunden linear.

Die Pufferkomposition beeinflußt signifikant die Funktion des Enzyms; in Tris-HCl Puffer $(\mathrm{pH} 7,2)$ bei $37^{\circ} \mathrm{C}$ ist die Aktivität 1,35fach höher als in Phosphat-Puffer $(\mathrm{pH} 7,3)$ und die Temperaturkorrekturfaktoren sind ebenfalls verschieden für beide Puffersysteme.

$0,003 \mathrm{~mol} / 1$ der lathyrogenen Substanz $\beta$-Aminopropionitril hemmt die Aktivität um 50\%, wohingegen $\mathrm{Cu}^{2+}$ bis zu einer Konzentration von $130 \mu \mathrm{mol} / \mathrm{l}$ ohne Einfluß auf die Enzymaktivität ist.

Intra- und inter-serielle Präzision sind gekennzeichnet durch Variationskoeffizienten von 3,6 bzw $12 \%$.

Hämolyse und Hyperbílirubinämie interferieren nicht mit der Bestimmung, in hyperlipidämischen Seren wurden jedoch erhöhte Enzymaktivitäten festgestellt.

Während der Lagerung des Serums bei Raumtemperatur nimmt die katalytische Funktion um etwa 30\%/Tag ab. 
Unter den 26 getesteten Kontrollseren enthalten nur wenige Monoaminoxidase-Aktivität, die quantitativ (d.h. vergleichbare katalytische Konzentration) und qualitativ (d. h. vergleichbare Sensitivität gegenüber $\beta$-Aminopropionitril und ähnliches Aktivitätsverhältnis in Tris-/Phosphat-Puffer) der in menschlichen Seren vorhandenen entspricht. Mithin sind nur wenige der kommerziell erhältlichen Kontrollseren für die Präzisionskontrolle dieser Bestimmung geeignet.

\section{Introduction}

A common sequel of diverse forms of chronic hepatocellular damage is the fibrotic change of the liver parenchy$\mathrm{ma}$. The process, which is characterized by strong accumulation of complex connective tissue proteins such as various types of collagens $(1,2)$ and proteoglycans $(3,4)$, is believed to involve stimulated synthesis rather than reduced breakdown of the intercellular macromolecules $(5-8)$. Despite its great clinical significance, the early diagnosis and therapeutic monitoring of hepatic fibroproliferation by biochemical means is presently hindered by a limited supply of reliable and practicable clinical-chemical parameters $(9-11)$. Of these, the determination of the activity of monoamine oxidase (monoamine: $\mathrm{O}_{2}$ oxidoreductase, EC 1.4.3.4) in serum has been proposed as a useful, supplementary diagnostic procedure for organ fibrosis, in particular for active hepatic fibrosis (12-14). Reported data $(15,16)$ suggest the superiority of this enzyme to other currently available biochemical markers of liver fibrosis, but direct and quantitative comparisons have not yet been published. In order to make the determination of the activity of monoamine oxidase in human serum suitable for standardized routine clinical use and interlaboratory comparisons, it seemed necessary to us to study some important properties of the enzyme and of the recently developed, simplified, colorimetric assay system (15).

\section{Materials and Methods}

\begin{abstract}
Materials
1-[(4-aminomethyl-phenyl)azo]-2-naphthol hydrochloride was purchased from Wako Pure Chemical Industries, Osaka, Japan; $\beta$-aminopropionitrile fumarate (lot 108 C-0164) was from Sigma Chemical Comp., München, FRG; phosphate buffer solution $\left(0.067 \mathrm{~mol} / \mathrm{l}, \mathrm{pH} 7.3\left(20^{\circ} \mathrm{C}\right)\right.$, lot $\left.203209 \mathrm{~A}\right)$ and the clearing agent for turbid sera (Frigen) were from Behring Institute, Marburg/Lahn, FRG; Sure-Sep II serum-plasma seperator was from General Diagnostics, Morris Plains, USA; the sources of control sera are listed in table 3 . All other reagents were of analytical grade.
\end{abstract}

\section{Methods}

Serum was prepared by centrifugation of venous blood which had been allowed to clot for 1 hour at room temperature, using the Sure-Sep II serum-plasma separator. Platelet-free plasma was obtained by anticoagulation of $3 \mathrm{ml}$ of blood in heparin-(Sarstedt, № 358) or ethylenediaminetetraacetate (EDTA)-(Sarstedt, $\mathrm{N}$ - 328) containing test tubes and subsequent centrifugation, using the Sure-Sep II serum-plasma separator.

In principle the activity of monoamine oxidase in sera was determined according to the method of Ono et al. (15). $0.5 \mathrm{ml}$ serum were incubated for one hour at $37^{\circ} \mathrm{C}$ with $1.0 \mathrm{ml}$ of 1-[(4-ami- nomethyl-phenyl)azol-2-naphthol hydrochloride $(0.5 \mathrm{mmol} / \mathrm{l})$ and an equal volume of $0.1 \mathrm{~mol} / 1 \mathrm{Tris}-\mathrm{HCl}$ buffer, $\mathrm{pH} 7.2\left(20^{\circ} \mathrm{C}\right)$. The reaction was terminated by the addition of $0.1 \mathrm{ml}$ perchloric acid, and 1-[(4-formylphenyl)azo]-2-naphthol formed during incubation was extracted with cyclohexane and quantitated by measuring its absorbance at $500 \mathrm{~nm}$ against cyclohexane. The calculation of the enzyme activity was based on the reported molar absorptivity of the reaction product (15). Modifications of this general procedure are described in the legends of the appropriate figures and tables.

\section{General determinations}

Hemoglobin was determined according to clinical-chemical standard procedures (17), total bilirubin (18) and triglycerides (19) were measured in a DuPont Automatic Clinical Analyzer and GEMSAEC fast analyzer, respectively.

\section{Results}

The time-course of the monoamine oxidase assay in human serum and two quality control sera is shown in figure 1 . The reaction proceeds linearly with time for at least 2 hours, but marked differences were noted in the activities of the enzyme depending on the buffer system used. Monoamine oxidase in Seronorm (fig. 1a) was over 4 times more active in phosphate buffer than in Tris$\mathrm{HCl}$, whereas the enzyme in human serum (fig. 1c) had 1.3 fold elevated activities in Tris $\mathrm{HCl}$ buffer as compared with phosphate buffer. On the other hand, enzyme activity in Precipath (fig. 1b) was only slightly influenced by the composition of the buffer during an incubation time of about $80 \mathrm{~min}$.

The serum containing the highest activity of monoamine oxidase (Seronorm) was used to study the effect of enzyme concentration on the reaction rates at different temperatures (fig. 2). The enzyme activity increased proportionally at least up to $6 \mathrm{kU} / \mathrm{l}$ which is about 15 times above the activity in normal human serum. The activity of the enzyme in Tris- $\mathrm{HCl}$ buffer at $37^{\circ} \mathrm{C}$ was about $60 \%$ of that in phosphate buffer at $30^{\circ} \mathrm{C}$ and increased linearly with serum volume only up to $1.7 \mathrm{kU} / 1$. At an incubation temperature of $46^{\circ} \mathrm{C}$ a sigmoidal activity curve reaching a plateau at about $10 \mathrm{kU} / \mathrm{l}$ was observed. The temperature correction factors and temperature-dependent tris/phosphate activity ratios of monoamine oxidase in human serum and Seronorm are summarized in table 1 . In agreement with the information given in figure 1 the data show clearly significant differences between the enzymes in both sera, in particular a strong and differential effect of incubation temperature on the enzyme activity in Tris- $\mathrm{HCl}$ and phosphate buffer, respectively. 


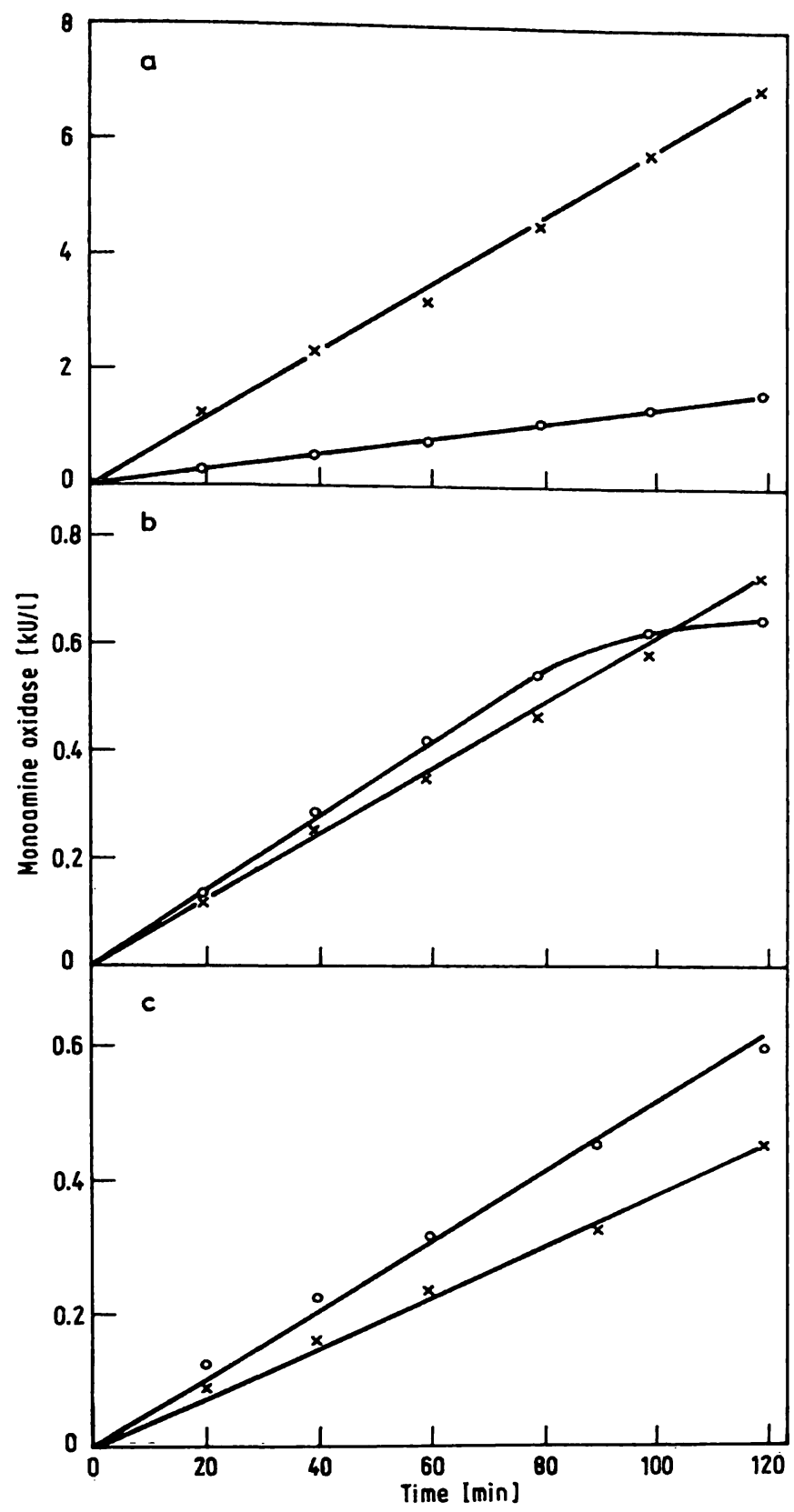

Fig. 1. The time-course of monoamine oxidase assay in control sera and human serum.

The activities were determined in Seronorm (a), Precipath (b) and in pooled normal human sera (c) either in the presence of Tris- $\mathrm{HCl}(\mathrm{pH} \mathrm{7.2)} \mathrm{(o-0)} \mathrm{or} \mathrm{phosphate}$ (pH 7.3) $(x-x)$ buffer. The mean activities of 6 determinations are given.

The adverse effects of the lathyrogenic compound $\beta$-aminopropionitrile on monoamine oxidase activity in human serum and Seronorm are illustrated by fiğure 3 . In human serum $50 \%$ inhibition is reached at $0.003 \mathrm{~mol} / \mathrm{l}$, complete inhibition at $0.150 \mathrm{~mol} / 1$. In the control serum, however, the activity was found to be greatly stimulated by the drug. The strongest increase (nearly 2.5 fold) was observed at $0.080 \mathrm{~mol} / 1 / \beta$-aminopropionitrile.

The results of intra- and inter-assay precision analyses are shown in table 2 . The accuracy of the test is difficult to assess at present since no adequate control sera are ob-

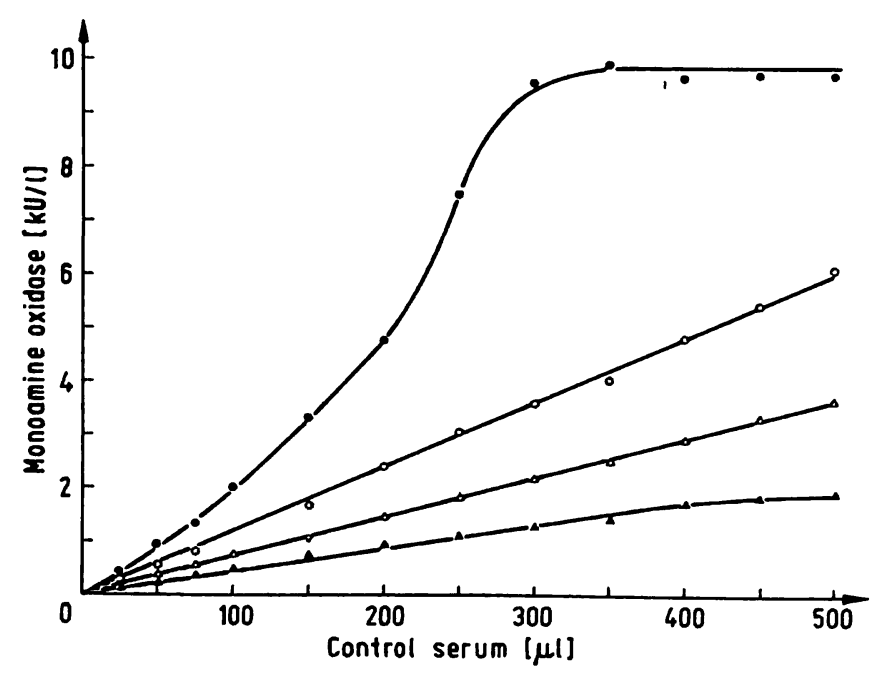

Fig. 2. The effect of enzyme concentration on the reaction rate, depending on the incubation temperature and buffer composition.

Increasing volumes of Seronorm were incubated with Substrate for $1 \mathrm{~h}$ in the presence of either Tris- $\mathrm{HCl}$ buffer at $37^{\circ} \mathrm{C}(\wedge-\Delta)$, phosphate buffer at $37^{\circ} \mathrm{C}\left(\mathrm{O}_{-} \mathrm{O}\right)$, phosphate buffer at $30^{\circ} \mathrm{C}(\Delta-\Delta)$, or phosphate buffer at $46^{\circ} \mathrm{C}(\bullet-\bullet)$. Each value represents the mean activity of 6 measurements.

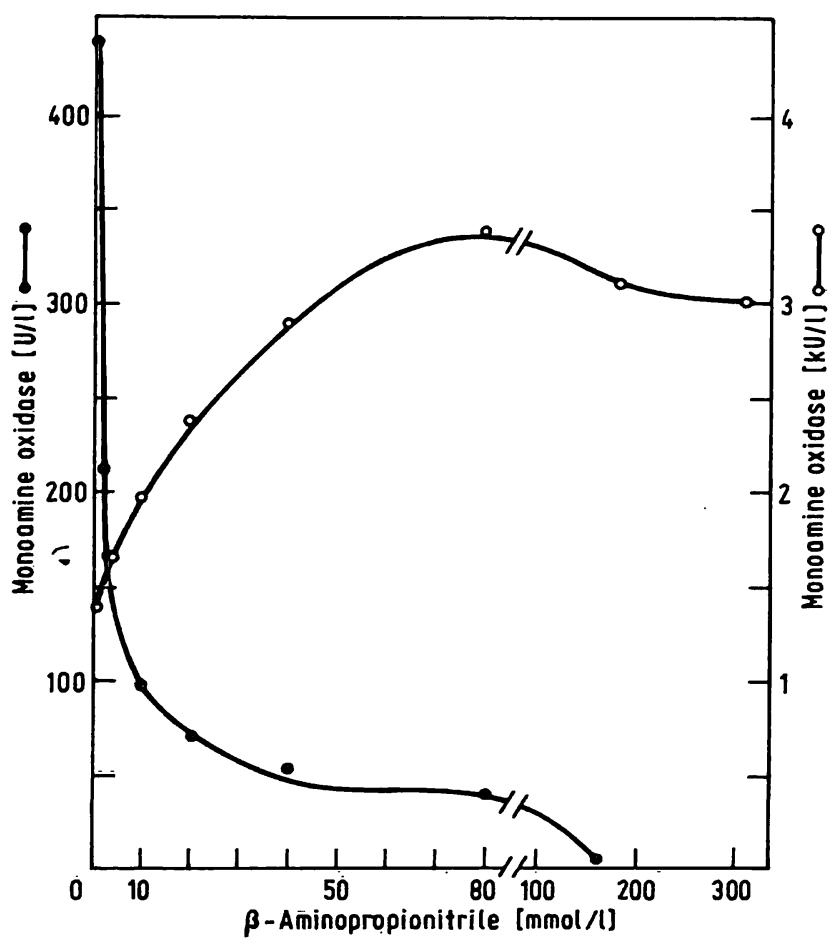

Fig. 3. The effect of $\beta$-amino-propionitrile on the activity of monoamine oxidase in normal human serum ( $\bullet-)$ and in a quality control serum (Seronorm, o- - ). Each point represents the mean activity of 4 determinations, which were performed in Tris- $\mathrm{HCl}$ buffer.

tainable. Applying the above mentioned criteria (tris/ phosphate activity ratio, effect of $\beta$-aminopropionitrile) a series of commercially available quality control sera was analysed for monoamine oxidase to select the most 
Tab. 1. The effect of temperature on the buffer-dependent activity of monoamine oxidase in a quality control serum (Seronorm) and normal human serum.

The samples were incubated for 1 hour at $20^{\circ} \mathrm{C}, 30^{\circ} \mathrm{C}$ and $37^{\circ} \mathrm{C}$ either in the presence of a Tris- $\mathrm{HCl}(\mathrm{pH} 7.2)$ or phosphate buffer ( $\mathrm{pH} 7.3$ ) as described in fig. 1 . The conversion factors and activity ratios were calculated from 4 independent measurements.

\begin{tabular}{|c|c|c|c|c|c|c|c|}
\hline \multirow[t]{2}{*}{ Serum } & \multirow[t]{2}{*}{ Buffer system } & \multicolumn{3}{|c|}{ Conversion factors } & \multicolumn{3}{|c|}{ Activity ratio (tris/phosphate) } \\
\hline & & $20^{\circ} \rightarrow 30^{\circ} \mathrm{C}$ & $30^{\circ} \rightarrow 37^{\circ} \mathrm{C}$ & $20^{\circ} \rightarrow 37^{\circ} \mathrm{C}$ & $20^{\circ} \mathrm{C}$ & $30^{\circ} \mathrm{C}$ & $37^{\circ} \mathrm{C}$ \\
\hline Seronorm & $\begin{array}{l}\text { tris } \\
\text { phosphate }\end{array}$ & $\begin{array}{l}4.48 \\
2.75\end{array}$ & $\begin{array}{l}2.35 \\
2.57\end{array}$ & $\begin{array}{l}7.40 \\
7.08\end{array}$ & 0.32 & 0.26 & 0.23 \\
\hline Human serum & $\begin{array}{l}\text { tris } \\
\text { phosphate }\end{array}$ & $\begin{array}{l}2.80 \\
3.19\end{array}$ & $\begin{array}{l}2.01 \\
2.21\end{array}$ & $\begin{array}{l}5.63 \\
7.06\end{array}$ & 1.64 & 1.43 & 1.31 \\
\hline
\end{tabular}

Tab. 2. Intra- and inter-assay precision of the determination of monoamine oxidase activity in serum. The values are the mean \pm S.D. of 25 measurements.

\begin{tabular}{|c|c|c|c|c|c|}
\hline \multirow[t]{2}{*}{ Control serum } & \multirow{2}{*}{$\begin{array}{l}\text { Mono- } \\
\text { amine } \\
\text { oxidase } \\
(\mathrm{U} / \mathrm{l})\end{array}$} & \multicolumn{2}{|c|}{ Intra-assay } & \multicolumn{2}{|c|}{ Inter-assay } \\
\hline & & $\begin{array}{l}\text { S.D. } \\
(U / 1)\end{array}$ & $\begin{array}{l}\mathrm{CV} \\
(\%)\end{array}$ & $\begin{array}{l}\text { S.D. } \\
(U / 1)\end{array}$ & $\begin{array}{l}\mathrm{CV} \\
(\%)\end{array}$ \\
\hline $\begin{array}{l}\text { Hyland P } \\
\text { Precipath } \\
\text { Seronorm }\end{array}$ & $\begin{array}{r}91 \\
412 \\
1640\end{array}$ & $\begin{array}{l}2.5 \\
15 \\
77\end{array}$ & $\begin{array}{l}2.7 \\
3.6 \\
4.7\end{array}$ & $\begin{array}{r}13 \\
54 \\
157\end{array}$ & $\begin{array}{c}14 \\
13 \\
9.6\end{array}$ \\
\hline
\end{tabular}

suitable ones for routine quality control (table 3). Among the 26 sera tested 11 contained monoamine oxidase quantitatively and qualitatively similar (albeit not identical) to that in sera of normal and liver-cirrhotic human subjects (table 3 ). The remaining sera had enzyme activities definitely different from the human type and, hence, are not favourable to precision control analyses of monoamine oxidase assay in normal and pathologic human sera. It should be noted, that among the mixed type sera originating mainly from animal and less from human sources, Wellcomtrol 1,3 , and 2 contained the highest activities, but the enzyme in the last mentioned serum was not influenced by the lathyrogenic drug.

The conditions of storage of the sample are of great importance for a correct analysis (fig. 4). If the serum is kept at room temperature the activity of monoamine oxidase declines very rapidly, during the first $48 \mathrm{~h}$ by $30 \% /$ day. Best preservation of catalytic function in sera is achieved either by deep-freezing, or by storage at $+4{ }^{\circ} \mathrm{C}$ (fig. 4 ).

Hemolysis and hyperbilirubinemia do not interfere significantly with the assay of monoamine oxidase activity in human serum (tab. 4). In hyperlipemic sera a significant increase in the activity was noted which can be avoided by delipidation of the serum with Frigen based agents prior to use (table 4). In no case, there was a need to perform blank incubations, i.e. serum added after termination of the reaction.

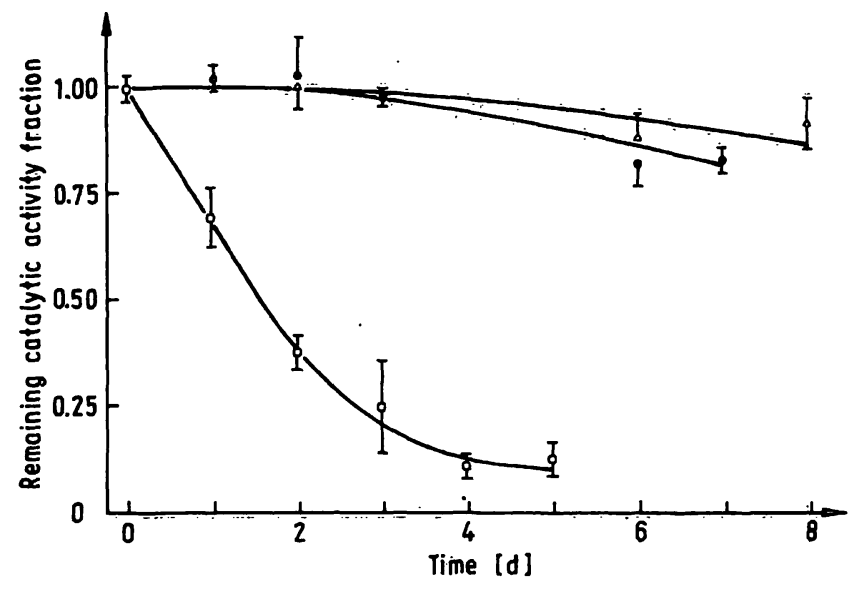

Fig. 4. The dependency of serum monoamine oxidase activity on the conditions of storage.

Sera from 10 healthy persons were pooled and divided into 3 equal portions, which were stored for various times either at $22^{\circ} \mathrm{C}$ (room temperature, $\square-0$ ), at $4{ }^{\circ} \mathrm{C}(\bullet-)$ or in aliquots at $-20^{\circ} \mathrm{C}(\Delta-\Delta)$. The percentage of the remaining activity (mean value $\pm S$.D. of 6 determinations) is shown.

The activities of monoamine oxidase in serum, ethylenediaminetetraacetate (EDTA)- and heparin-aniticoagulated, platelet-free plasma of 8 healthy persons were $374 \pm 99$ $\mathrm{U} / 1,377 \pm 93 \mathrm{U} / 1$ and $390 \pm 100 \mathrm{U} / \mathrm{l}$, respectively. Thus, serum and plasma seem to be interchangeable for the determination of monoamine oxidase.

The activities of monoamine oxidase in the sera of 178 healthy persons are listed in table 5. They do not show significant sex-related differences. In the age groups (18 to 55 years) tested no effect of age on enzyme activity was noted (data not shown).

Increases in the concentration of $\mathrm{Cu}^{2+}$ and $\mathrm{Mg}^{2+}$ up to $130 \mu \mathrm{mol} / 1$ and $20 \mathrm{mmol} / \mathrm{l}$ incubation mixture, respectively, are without effect on the activity of monoamine oxidase.

\section{Discussion}

Human blood serum contains a soluble monoamine oxidase thàt deaminates a variety of monoamines including 
Tab. 3. The influence of buffer composition and $\beta$-aminopropionitrile on the activity of monoamine oxidase in various quality control sera in comparison with human serum from normal and liver cirrhotic subjects.

presence of $\beta$-aminopropionitrile (final Tris- $\mathrm{HCl}(\mathrm{pH} \mathrm{7.2)}$ and phosphate (pH 7.3) buffer, respectively, either in the absence or was between 3.5 and $5 \%$

\begin{tabular}{|c|c|c|c|c|c|c|}
\hline \multirow[t]{2}{*}{ Control serum (producer) } & \multirow[t]{2}{*}{ Lot No. } & \multicolumn{2}{|c|}{$\begin{array}{l}\text { Monoamine oxidase } \\
(\mathrm{U} / \mathrm{l})\end{array}$} & \multirow{2}{*}{$\begin{array}{l}\text { Ratio } \\
\text { of activity } \\
\text { Tris/ } \\
\text { Phosphate }\end{array}$} & \multicolumn{2}{|c|}{ Inhibition (\%) } \\
\hline & & Tris & Phosphate & & Tris & Phosphate \\
\hline $\begin{array}{l}\text { Normal human serum } \\
\text { Cirrhotic human serum }\end{array}$ & - & $\begin{array}{l}284 \\
902\end{array}$ & $\begin{array}{l}215 \\
600\end{array}$ & $\begin{array}{l}1.32 \\
1.50\end{array}$ & $\begin{array}{l}-89 \\
-92\end{array}$ & $\begin{array}{l}-91 \\
-90\end{array}$ \\
\hline \multicolumn{7}{|l|}{ Sera of human type } \\
\hline $\begin{array}{l}\text { Flui Norm N (Behring) } \\
\text { Flui Norm P (Behring) } \\
\text { Precilip (Boehringer) } \\
\text { PKR (ASID) } \\
\text { Ortho Ria II (Ortho Diagnostics) } \\
\text { Ortho Ria I (Ortho Diagnostics) } \\
\text { Ortho Normal (Ortho Diagnostics) } \\
\text { Ortho Abnormal (Ortho Diagnostics) } \\
\text { Standard human plasma (Behring) } \\
\text { Precipath E (Boehringer) } \\
\text { Monitrol II-E (DADE) }\end{array}$ & $\begin{array}{l}134 \text { B } \\
144 \text { H } \\
661 \\
\text { H } 1245-1 \\
2 S 507 \\
\text { 3S } 407 \\
\text { S R } 215 \\
9 S 317 \\
502533 \text { B } \\
833 \\
\text { PTD-60 A }\end{array}$ & $\begin{array}{l}102 \\
102 \\
118 \\
139 \\
167 \\
176 \\
203 \\
240 \\
392 \\
539 \\
720\end{array}$ & $\begin{array}{r}73 \\
82 \\
80 \\
96 \\
132 \\
143 \\
172 \\
198 \\
345 \\
450 \\
599\end{array}$ & $\begin{array}{l}1.40 \\
1.24 \\
1.48 \\
1.45 \\
1.27 \\
1.23 \\
1.18 \\
1.21 \\
1.14 \\
1.20 \\
1.20\end{array}$ & $\begin{array}{l}-90 \\
-90 \\
-82 \\
-87 \\
-88 \\
-82 \\
-86 \\
-87 \\
-78 \\
-74 \\
-85\end{array}$ & $\begin{array}{l}-86 \\
-88 \\
-75 \\
-66 \\
-59 \\
-67 \\
-76 \\
-61 \\
-75 \\
-65 \\
-77\end{array}$ \\
\hline \multicolumn{7}{|l|}{ Sera of mixed type } \\
\hline $\begin{array}{l}\text { Bilirubin Control (DADE) } \\
\text { Q-Pak (Hyland Division) } \\
\text { Hyland N (Hyland Division) } \\
\text { Hyland P (Hyland Division) } \\
\text { Seroquant (Behring) } \\
\text { Kontrollogen L (Behring) } \\
\text { Monitrol I-E (DADE) } \\
\text { Precinorm U (Boehringer) } \\
\text { Normosic (ASID) } \\
\text { Validate A (Gödecke) } \\
\text { Seronorm (Nyegaard) } \\
\text { Wellcomtrol } 2 \text { (Wellcome) } \\
\text { Pathonorm L (Nyegaard) } \\
\text { Wellcomtrol } 1 \text { (Wellcome) } \\
\text { Wellcomtrol } 3 \text { (Wellcome) }\end{array}$ & $\begin{array}{l}\text { BIC-940 } \\
1838 \text { UOO 2AAD } \\
\text { N } 05 \text { A } \\
\text { P } 11 \text { E } \\
624103 \\
3106 \mathrm{~K} \\
\text { LTD-147 B } \\
839 \\
414 \text { B } \\
0641117 \\
147 \\
\text { K } 7489 \\
12 \\
\text { K } 7486 \\
\text { K } 7490\end{array}$ & $\begin{array}{r}32 \\
75 \\
100 \\
103 \\
109 \\
120 \\
142 \\
153 \\
201 \\
475 \\
1071 \\
2710 \\
4488 \\
5307 \\
7242\end{array}$ & $\begin{array}{r}17 \\
61 \\
85 \\
109 \\
122 \\
108 \\
134 \\
297 \\
247 \\
458 \\
4596 \\
5150 \\
3107 \\
9442 \\
9045\end{array}$ & $\begin{array}{l}1.88 \\
1.23 \\
1.18 \\
0.94 \\
0.89 \\
1.11 \\
1.06 \\
0.52 \\
0.81 \\
1.04 \\
0.23 \\
0.53 \\
1.44 \\
0.56 \\
0.80\end{array}$ & $\begin{array}{l}-53 \\
-63 \\
-61 \\
-62 \\
-76 \\
-81 \\
-77 \\
-58 \\
-82 \\
-83 \\
+103 \\
0 \\
-49 \\
-52 \\
-70\end{array}$ & $\begin{array}{l}+259 \\
-57 \\
-53 \\
-67 \\
-85 \\
-66 \\
-75 \\
-77 \\
-68 \\
-72 \\
-15 \\
0 \\
-28 \\
-65 \\
-71\end{array}$ \\
\hline
\end{tabular}

benzylamine, tyramine, tryptamine, dopamine and phenylethylamine $(21,22)$. Neither the physiological role nor the origin of the circulating form of monoamine oxidase are known. In its substrate specifity it resembles the type B (23-25) mitochondrial outer membrane monoamine oxidase, but the inhibition by lathyrogens $(26,27)$, such as $\beta$-aminopropionitrile, and electrophoretic mobility clearly indicate marked differences between these two enzymes $(12,28)$. As a further criterion we showed that the serum enzyme is insensitive to $\mathrm{Cu}^{2+}$, whereas the liver mitochondrial enzyme was reported to be strongly inactivated (29).

Previous studies have demonstrated elevated enzyme activities under several pathological conditions, especially in progressive hepatic fibrosis $(12-16,30-32)$. The latter observation established the diagnostic significance of the enzyme and suggested that it might catalyze the initial step of collagen cross-linking in the liver $(12,31$, 32). However, purified amine oxidase does not utilize collagen substrates (33) and is antigenically different from liver lysyl oxidase (34), which also increases in the serum of liver-fibrotic rats (35). Thus, the role of serum monoamine oxidase in hepatic connective tissue metabolism remains obscure.

Obviously serum monoamine oxidase is composed of multiple, biologically undefined forms (15) of which the quantitative relation might change in certain pathological states (32). Modifications of the assay conditions can therefore selectively affect the activity pattern of the isoenzymes of monoamine oxidase in health and disease. We have shown that there is an increase in the activity of the human serum enzyme if the phosphate buffer originally used by Mc Ewen \& Cohen (21) is replaced by Tris$\mathrm{HCl}$ buffer, and, furthermore; that the temperature correction factors are different for the two buffer systems. According to our results, sera from cirrhotic patients contain monoamine oxidase that is qualitatively similar to that in normal serum, but differences in the isoenzyme composition have been described $(32,36,37)$. It should be emphasized that quality control of the assay 
Tab. 4. Interferences of hemolysis, hyperlipemia, and bilirubinemia with the determination of monoamine oxidase activity in human serum. Increasing volumes of concentrated stock solutions were added to normal human sera to get final concentrations of hemoglobin, triglycerides, and bilirubin, respectively, as listed. A solution of $4.22 \mathrm{mmol} / 1$ hemoglobin was obtained by hemolysis of washed erythrocytes in distilled water by repeated freezing and thawing. A triglyceride$(12.8 \mathrm{mmol} / \mathrm{l})$ and cholesterol- $(9.7 \mathrm{mmol} / \mathrm{l})$ rich solution was prepared from pooled hyperlipemic human sera. The sera were centrifuged $\left(8 \mathrm{~h}, 4^{\circ} \mathrm{C}, 30000 \mathrm{~g}\right)$ and the lipid-rich supernatant, which was free of monoamine oxidase activity, was aspirated. Bilirubin Control (DADE, lot BIC-941) was dissolved in water to get a solution of $513 \mu \mathrm{mol} / 1$ bilirubin. Some of the sera were delipidized with Frigen (20). Blank incubations were performed by adding the sera after termination of the reaction. Absorptivity of blank and sample incubations were measured against cyclohexane. The mean activities \pm S.D. of 6 determinations are given.

\begin{tabular}{|c|c|c|c|c|}
\hline & \multirow[t]{2}{*}{$\Delta \mathrm{A}_{\text {blank }}$} & \multirow{2}{*}{$\Delta \mathrm{A}_{\text {sample }}$} & \multicolumn{2}{|c|}{$\begin{array}{l}\text { Monoamine } \\
\text { oxidase } \\
\text { (U/1) }\end{array}$} \\
\hline & & & $\bar{x} \pm$ & S.D. \\
\hline \multicolumn{5}{|l|}{ Hemoglobin (mmol/l) } \\
\hline $\begin{array}{l}0 \\
0.422 \\
0.844\end{array}$ & $\begin{array}{l}0.003 \\
0.003 \\
0.004\end{array}$ & $\begin{array}{l}0.068 \\
0.065 \\
0.063\end{array}$ & $\begin{array}{l}335 \\
320 \\
310\end{array}$ & $\begin{array}{l}10 \\
12 \\
24\end{array}$ \\
\hline \multicolumn{5}{|l|}{ Trigly cerides (mmol/l) } \\
\hline $\begin{array}{l}1.49 \\
4.06 \\
4.06 \text { (treated with Frigen) } \\
6.62\end{array}$ & $\begin{array}{l}0.001 \\
0.001 \\
0.001 \\
0.002\end{array}$ & $\begin{array}{l}0.099 \\
0.122 \\
0.099 \\
0.125\end{array}$ & $\begin{array}{l}483 \\
597 \\
483 \\
610\end{array}$ & $\begin{array}{l}22 \\
34 \\
19 \\
35\end{array}$ \\
\hline \multicolumn{5}{|l|}{ Bilirubin $(\mu \mathrm{mol} / \mathrm{l})$} \\
\hline $\begin{array}{r}9.2 \\
60.5 \\
214.4\end{array}$ & $\begin{array}{l}0.001 \\
0.000 \\
0.001\end{array}$ & $\begin{array}{l}0.066 \\
0.074 \\
0.073\end{array}$ & $\begin{array}{l}325 \\
363 \\
360\end{array}$ & $\begin{array}{l}17 \\
21 \\
10\end{array}$ \\
\hline
\end{tabular}

\section{References}

1. Rojkind, M., Giambrone, M.-A. \& Biempica, L. (1979), Gastroenterology 76, 710-719.

2. Seyer, J. M., Hutcheson, E. T. \& Kang, A. H. (1977), J. Clin. Invest. 59, 241-248.

3. Kojima, J., Nakamura, N., Kanatani, M. \& Ohmori, K. (1975), Cancer Res. 35, 542-547.

4. Delbrück, A. (1968), Z. Klin. Chem. Klin. Biochem. 6, 460466.

5. Chen; Th. S. N. \& Leevy, C. M. (1975), J. Lab. Clin. Med. $85,103-112$.

6. Rojkind, M. \& Dunn, M. A. (1979), Gastroenterology 76, 849-863.

7. Gressner, A. M., Pazen, H. \& Greiling, H. (1977), Experientia $33,1290-1292$.

8. McGee, J. O. D., Patrick, R. S., Rodger, M. C. \& Luty, C. M. (1974), Gut 15, 260-267.

9. Pott, G. \& Gerlach, M. (1977), Med. Welt 28, 2030-2034.

10. Gressner, A. M. (1979), Lab. med. 3, 201-208.

11. Gressner, A. M. (1980), Med. Welt 31, 11-16.

12. Ito, K., Nakagawa, J., Minakuchi, C. \& Fukase, M. (1971), Digestion 4, 49-58.

13. Kirchner, J. P. \& Castell, D. O. (1972), Gastroenterology 62,771 .
Tab. 5. Reference ranges for the activity of serum monoamine oxidase. The enzyme was determined in the sera of 178 biochemically and clinically healthy persons ranging from 18 to 55 years according to the standard assay procedure using Tris- $\mathrm{HCl}$ buffer.

\begin{tabular}{lllll}
\hline & & \multicolumn{3}{l}{ Monoamine oxidase activity } \\
& & $(\mathrm{U} / \mathrm{l})$ & & \\
& $\mathrm{n}$ & $-2 \mathrm{~s}$ & mean & $+2 \mathrm{~s}$ \\
\hline Men & 109 & 148 & 380 & 612 \\
Women & 69 & 106 & 390 & 674 \\
\hline
\end{tabular}

conditions is comlicated by the fact that only few commercially available control sera contain monoamine oxidase approximating to the human serum type. The variable degrees of the inhibition (in Seronorm even strong activation!) by $\beta$-aminopropionitrile suggest the presence of variable amounts of type $B$ tissue monoamine oxidase in the sera, which might also explain their different Tris/ phosphate activity ratios.

Although the within-run precision is satisfactory, the disadvantages (large sample volumes, time-consuming and manual procedure, relative insensitivity) of even the improved colorimetric mothod (15) hinder its frequent application in the routine diagnosis of hepatic fibroproliferation. To overcome these drawbacks we are currently developing a sensitive and rapid kinetic procedure for the assay of monoamine oxidase activity in serum which can be fully mechanized.

Alternatively, immunologic quantitation seems favourable since it bypasses the marked instability of the enzyme activity at room temperature.
14. Nakano, H., Yamamoto, Y., Ohnishi, S., Ito, K. \& Imura, H. (1978), Clin. Chim. Acta 88, 315-319.

15. Ono, T., Eto, K., Sakata, Y. \& Takeda, M. (1975), J. Lab. Clin. Med. 85, 1022-1031.

16. McEwen, C. M. \& Castell, D. O. (1976), J. Lab. Clin. Med. $70,36-47$.

17. Richterich, R. \& Colombo, J. P. (1978), Klinische Chemie, 4. ed. S. Karger, Basel.

18. Jendrassik, L. \& Grof, P. (1938), Biochem. Z. 297, 81-89.

19. Eggstein, M. \& Kreutz, F. H. (1966), Klin. Wochenschr. 44, 262-267.

20. Voigt, H. W. (1977), Laboratoriumsblätter (Behring) 27 , $168-172$.

21. McEwen, C. M. \& Cohen, J. D. (1963), J. Lab. Clin. Med. 62, 766-776

22. McEwen, C. M. (1965), J. Biol: Chem. 240, 2003-2010.

23. Neff, N. H. \& Yang, H. Y. T. (1974), Life Sci. 14, 20612074.

24. Murphy, D. L. (1978), Biochem. Pharmacol. 27, 1889-1893.

25. Cawthon, R. M. \& Breakefield, X. O. (1979), Nature 281, 692-694.

26. Page, R. G. \& Benditt, E. P. (1967), Proc. Soc. Exp. Biol. Med. $124 ; 454-459$. 
27. De Marco, C., Coletta, M. \& Bombardieri, G. (1965), Nature $205,176$.

28. Ito, K., Nakagawa, J., Minakuchi, C. \& Fukase, M. (1969), Abstr. 64th Congr. Jap. Soc. Gastroent.

29. Magour, S., Cumpelik, O. \& Paulus, M. (1979), J. Clin. Chem. Clin. Biochem. 17, 777-780.

30. Nilsson, S. E., Tryding, N. \& Tufvesson, G. (1968), Acta Med. Scand. 184, 105-108.

31. Kirchner, J. P., Nebel, O. T. \& Castell, D. O. (1974), Mil. Med. 139, 952-954.

32. Malin, A. W. S., Davis, L. M. \& Castell, D. O. (1976), Proc. Soc. Exp. Biol. Med. 151, 40-43.
33. Siegel, R. C. (1979), Int. Rev. Connect. Tissue Res. 8, 73 118.

34. Yasunobu, K. T., Ishizaki, H. \& Minamiura, N. (1976), Mol. Cell. Biochem. 13, 3-29.

35. Siegel, R. C., Chen, K. H., Greenspan, J. S. \& Aguiar, J. M. (1978), Proc. Natl. Acad. Sci. USA 75, 2945-2949.

36. Malin, A. W. S. \& Castell, D. O. (1974), Biochem. Med. 9 , 373-385.

37. Malin, A. W. S. \& Castell, D. O. (1975), Biochem. Med. 13, $141-156$.
Priv.-Doz. Dr. med. A. M. Gressner

Abteilung Klinische Chemie und Pathobiochemie RWTH

Klinisch-Chemisches Zentrallaboratorium

der Medizinischen Fakultät

der Technischen Hochschule

(RWTH) Aachen

Goethestraße 27-29

D-5100 Aachen 


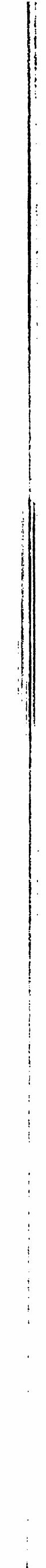

